\title{
Nucleophilic trifluoromethylation of some polycyclic ketones \#
}

\author{
Jarosław Romański* and Grzegorz Mlostoń \\ University of Łódź, Department of Organic and Applied Chemistry, \\ Section of Heteroorganic Compounds, Narutowicza 68, 90-136 Łódź, Poland \\ E-mail: romanski@uni.lodz.pl
}

\section{Dedicated to Prof. Jan Epsztajn on the occasion of his $75^{\text {th }}$ birthday}

\begin{abstract}
Ruppert's reagent $\left(\mathrm{CF}_{3}-\mathrm{SiMe}_{3}\right)$ was used in the reaction with derivatives of pentacyclo$\left[5.4 .0 .0^{2,6} \cdot 0^{3,10} \cdot 0^{5,9}\right]$ undecane-8,11-dione ('cage' dione) in the presence of dry CsF to yield trifluoromethyl $O$-silylated products. Subsequent acidic hydrolysis gave the corresponding hydroxy derivatives. In the case of the 'cage' dione the transannular cyclization leading to oxahexacyclic ( $O$-bridged) product was observed.
\end{abstract}

Keywords: Trifluoromethylation, polycyclic ketones, nucleophilic addition, transannular cyclization

\section{Introduction}

The chemistry of fluorinated compounds has been extensively explored in recent decades. It is well established that introduction of the trifluoromethyl group into a known substance results in significant changes in the chemical, physical and biological properties. ${ }^{1}$ Direct trifluoromethylation of aromatic compounds is mostly based on the reactions of in situ generated $\cdot \mathrm{CF}_{3}$ radical. ${ }^{2}$ The non-direct trifluoromethylation with $\mathrm{SF}_{4}$ used as a source of fluorine atoms has been developed by Dmowski. ${ }^{3}$ On the other hand, there are known methods that explore an ionic $\mathrm{CF}_{3}$-moiety, e.g. the sulfonium salt of type $\mathbf{1}$ is an efficient source of the trifluoromethyl cation (Scheme 1). ${ }^{4}$ In recent times, nucleophilic trifluoromethylation has been widely explored for introduction of the $\mathrm{CF}_{3}$-group using carbonyl substrates such as aldehydes, ketones or esters ${ }^{5}$ and trimethyl(trifluoromethyl)silane (3) known as the Ruppert's reagent. ${ }^{6}$

\footnotetext{
${ }^{\#}$ For the first time presented at $14^{\text {th }}$ European Symposium on Fluorine Chemistry, Poznań, Poland, July 11-16, 2004, Book of Abstracts, A-P-75, 164.
} 


$$
\begin{aligned}
& \mathrm{CF}_{3}-\mathrm{R} \longrightarrow \cdot \mathrm{CF}_{3}+\mathrm{Ar}-\mathrm{X} \stackrel{\left(20-160^{\circ} \mathrm{C}\right)}{\longrightarrow} \mathrm{Ar}-\mathrm{CF}_{3} \\
& \mathrm{R}=\text { e.g.: } \mathrm{Br}, \mathrm{I}, \mathrm{SiEt}_{3}, \mathrm{ZnX}, \mathrm{Cu}, \mathrm{COOMe} \\
& X=\mathrm{H} \text { or Hal } \\
& \mathrm{R}-\mathrm{OH}_{\mathrm{OH}}^{\mathrm{O}}+\mathrm{SF}_{4} \underset{\substack{-\mathrm{SOF} \\
-\mathrm{SO}}}{\stackrel{<0^{\circ} \mathrm{C}}{\longrightarrow}} \mathrm{R} \underset{\mathrm{F}}{\stackrel{\mathrm{O}}{\mathrm{O}} \frac{\mathrm{SF}_{4}}{-\mathrm{SOF}_{2}}}-\mathrm{R}-\mathrm{CF}_{3} \\
& { }_{\mathrm{CF}_{3}} \mathrm{SO}_{2} \mathrm{CF}_{3} \\
& 1
\end{aligned}
$$

\section{Scheme 1}

In the original protocol, tetrabutylammonium fluoride (TBAF) was used as a catalyst in the reaction of $\mathbf{3}$ with carbonyl compounds yielding the corresponding trifluoromethylated alcohols via $O$-silylated derivatives. ${ }^{7}$ At present, cesium fluoride seems to be a catalyst of choice. ${ }^{5 a}$ However recently, an efficient application of the new catalysts in nucleophilic trifluoromethylation was described. ${ }^{8}$

The relatively easily available polycyclic 'cage' ketones 6 and 9 can be used as building blocks for the preparation of more complex systems, including hosts in supramolecular chemistry. ${ }^{9}$ Adamantanone (2), which belongs to the polycyclic 'cage' structures, reacts easily with 3 yielding trimethylsilyl derivative $\mathbf{4}$ which after acidic hydrolysis can be easily converted to 2-(trifluoromethyl)adamantan-2-ol (5) (Scheme 2). ${ }^{10}$

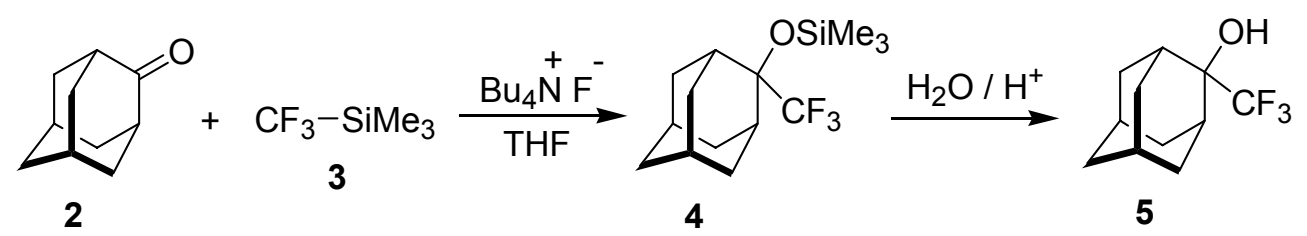

\section{Scheme 2}

In the case of the dione 9 reactions with primary amines, are reported to yield the corresponding monoimine derivatives which upon treatment with reducing agents $\left(\mathrm{NaBH}_{4}\right.$, $\mathrm{LiAlH}_{4}$ ) undergo a transannular cyclization via formation of the O-bridge. ${ }^{11}$ Reactivities of 6 and 9 have been studied in our group for some years and their ability to undergo transannular cyclization was observed in reactions with diverse O- and S-nucleophiles. ${ }^{12}$ The aim of the 
present study was to examine their reactions with Ruppert's reagent $\mathbf{3}$ and to elaborate a straightforward protocol for preparation of trifluoromethylated polycyclic alcohols.

\section{Results and Discussion}

The experiment with 3 and $\mathbf{6}$ was performed in dry 1,2-dimetoxyethane (DME) in the presence of catalytic amount of cesium fluoride (dried at 200-300 ${ }^{\circ} \mathrm{C}$ ). The expected $O$-silylated product 7 was smoothly obtained and subsequent hydrolysis followed by crystallization from hexane led to a colorless solid identified as alcohol 8 (Scheme 3).

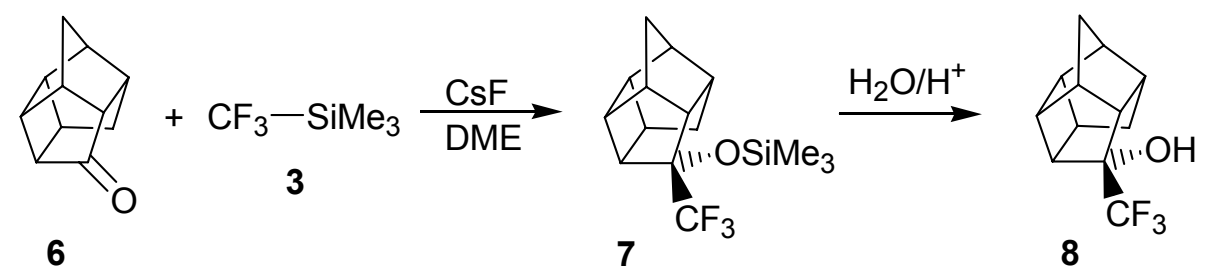

\section{Scheme 3}

The reaction occurs stereoselectively and the trifluoromethyl anion approaches the carbonyl group from the exo-face exclusively. As a result, the final product $\mathbf{8}$ contained the hydroxy group placed at the endo position as evidenced by the X-ray study. ${ }^{13}$

The reaction of 3 with 9 was carried out under analogous conditions. Depending on the molar ratio of substrates dione 9 was expected to react either with one or two equivalents of $\mathrm{CF}_{3}-\mathrm{SiMe}_{3}$ yielding mono- or bis-trifluoromethylated alcohols $\mathbf{1 0}$ or 11, respectively. The first attempted reaction of $\mathbf{9}$ with an equimolar amount of $\mathbf{3}$ was expected to yield the hydroxyketone $\mathbf{1 0}$ (Scheme 4).

After addition of $\mathrm{CF}_{3}-\mathrm{SiMe}_{3}$ an exothermic reaction started and after $1.5 \mathrm{~h}$ the conversion was complete. The initially formed trimethylsilyl derivative was hydrolyzed without isolation and crude product was purified by crystallization from hexane to give colorless crystals with a narrow melting point. The second experiment with two equivalents of $\mathrm{CF}_{3}-\mathrm{SiMe}_{3}$ should have led to 11, but unexpectedly the isolated product was identical with the substance obtained in the first entry; this result was confirmed by the absence of mixed melting point depression and by comparison of spectroscopic data. The IR-spectrum did not show the absorption band of the $\mathrm{C}=\mathrm{O}$ group suggesting that a transannular process took place. In the ${ }^{13} \mathrm{C}-\mathrm{NMR}$ spectra the characteristic signals appeared at $89.3\left(\mathrm{q},{ }^{2} \mathrm{~J}_{\mathrm{C}-\mathrm{F}}=34 \mathrm{~Hz}\right)$ and $120.0(\mathrm{~s}, \mathrm{O}-\mathrm{C}-\mathrm{O}) \mathrm{ppm}$, respectively. The MS-CI exhibited a molecular peak at $\mathrm{m} / \mathrm{z} 262\left[\mathrm{M}+1+\mathrm{NH}_{3}\right]^{+}$. Finally, the structure of trifluoromethylated hemiacetal 13 was unambiguously confirmed by the X-ray single crystal diffraction analysis (Fig.1). ${ }^{13}$ 

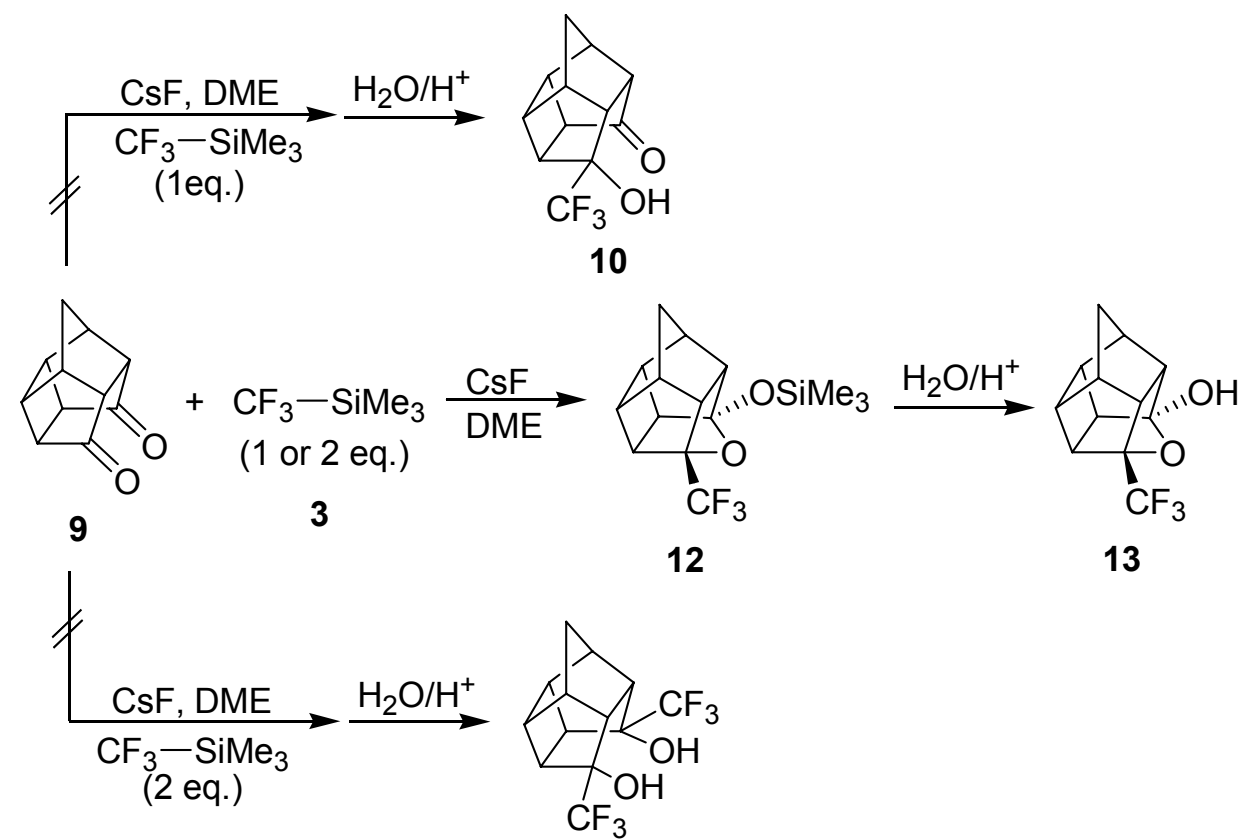

13

\section{Scheme 4}

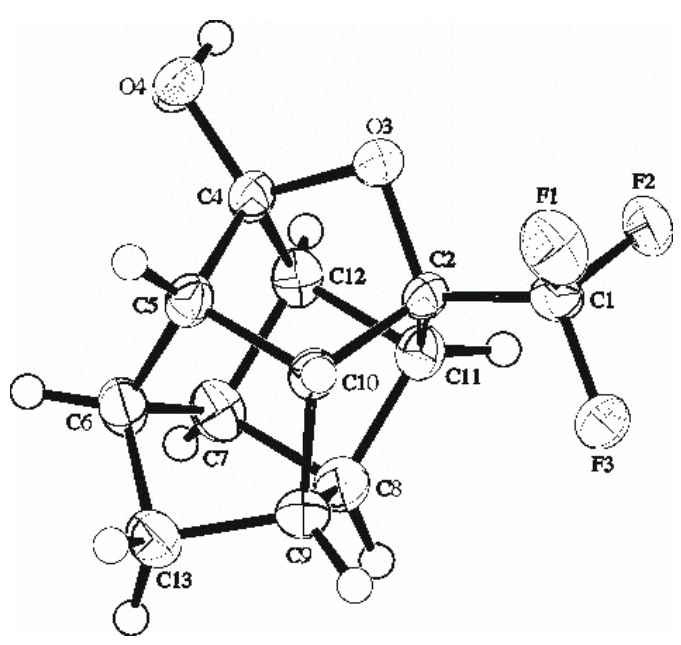

13

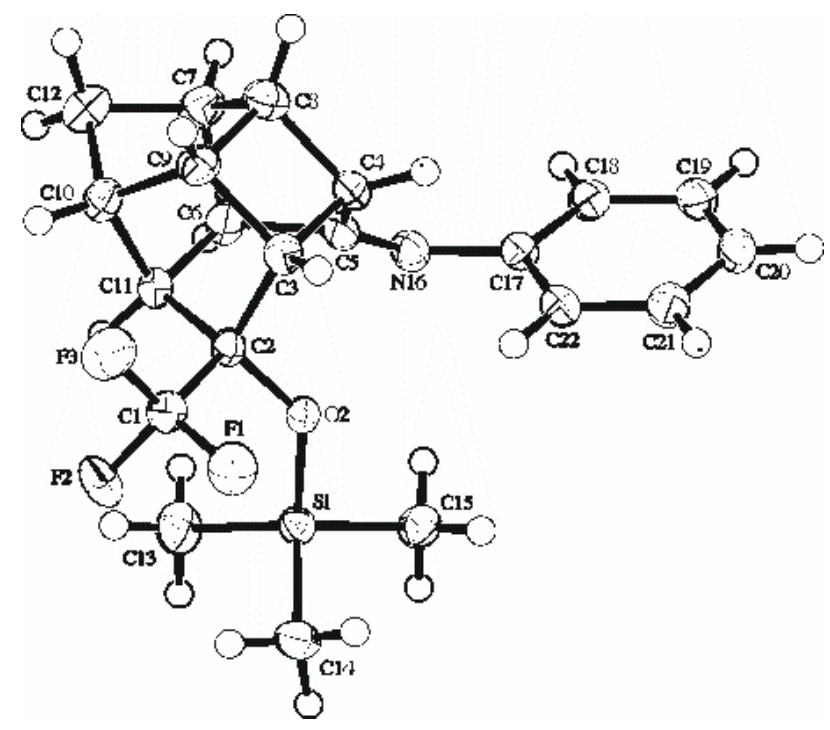

21

Figure 1. ORTEP-plots for compounds 13 and $21 .^{13}$

Noteworthy, the transannular cyclization under trifluoromethylation conditions was previously reported for the reaction of a 1,5-dione (i.e. bicyclo[3.3.1]nonane-2,6-dione) but in this case the successful formation of the product of bis-trifluoromethylation was reported. ${ }^{14}$ 
According to an other report the reaction of 1,4-dione (i.e. hexane-2,5-dione) with one or two equivalents of $\mathbf{3}$ did not afford the product of transannular cyclization. ${ }^{15}$ Recently, we have found that 9 easily reacts at low temperatures with amines as a nucleophilic agent and the formation of transannular cyclization products was established, ${ }^{16}$ instead of already reported aminoalcohol derivatives. $^{11}$

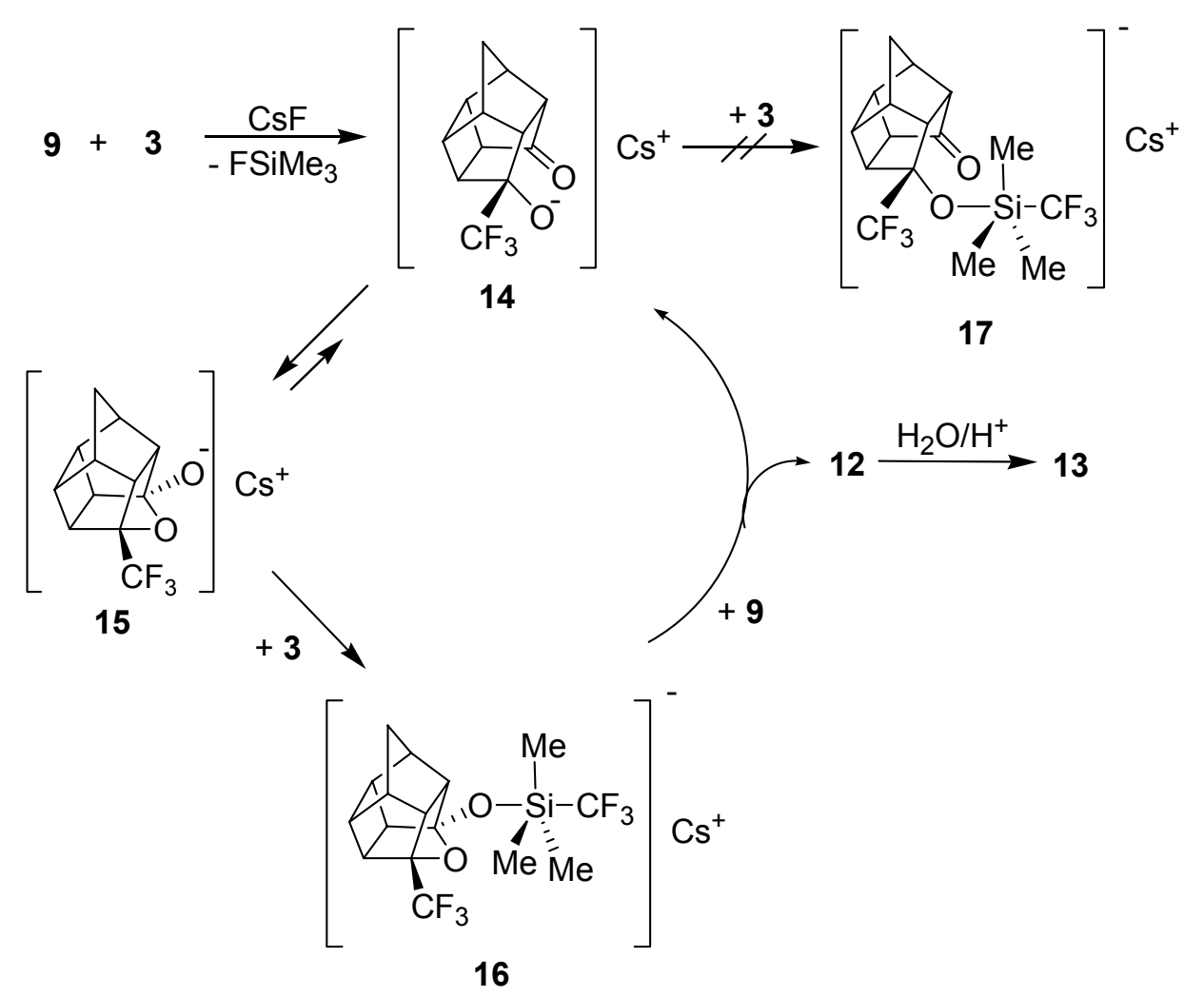

\section{Scheme 5}

The formation of $\mathbf{1 3}$ strongly supports the mechanistic pathway of the $\mathrm{CF}_{3}$-group addition to the carbonyl group formulated by Prakash et al. ${ }^{17}$ The first step of the reaction is the replacement of the $\mathrm{CF}_{3}$-group by the fluorine anion and trifluoromethide anion $\left(\mathrm{F}_{3} \mathrm{C}^{-}\right)$attacks the carbonyl group to form the salt of type 14. Apparently, the following transannular cyclization leading to $\mathbf{1 5}$ is faster than the addition of another molecule of $\mathbf{3}$ leading to the intermediate $\mathbf{1 7}$ which could give hydroxyketone 10. In the next step, reaction with another molecule of $\mathbf{3}$ generates a transient species 16 bearing pentacoordinated silicon atom. This intermediete rapidly transfers $\mathrm{F}_{3} \mathrm{C}$-group to the next molecule of $\mathbf{9}$ and the formation of the $O$-silylated acetal $\mathbf{1 2}$ is observed (Scheme 5).

In an extension of the above presented study, the C-C back-bond in the dione 9 was selectively reduced with zinc dust in refluxing glacial acetic acid yielding the 'released' ketone 18 (tetracyclo[6.3.0.0 $\left.0^{4,11} \cdot 0^{5,9}\right]$ undecane-2,7-dione). ${ }^{18}$ This ketone was treated with $\mathbf{3}$ in order to 
examine the limitation of transannular cyclization in this less strained structure. The distance between the two carbonyl groups, as evidenced by the X-ray study, is larger in comparison with 'cage' dione 9. ${ }^{19,21 \mathrm{~b}}$ The product isolated after reaction with $\mathbf{3}$ and subsequent hydrolysis exhibited no $\mathrm{C}=\mathrm{O}$ absorption, indicating the formation of hemiacetal 19; additional spectroscopic data are comparable with those registered for compound $\mathbf{1 2 .}$

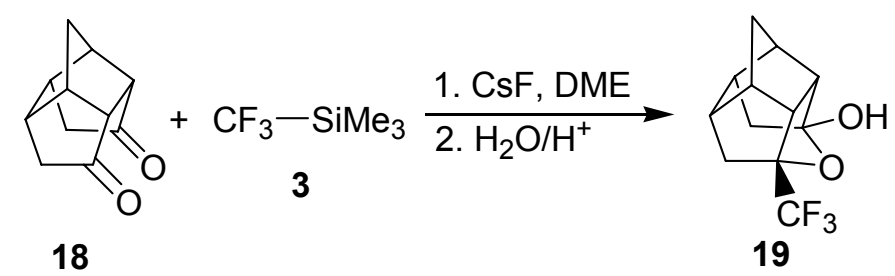

\section{Scheme 6}

In another experiment the imine 20 prepared in the reaction of aniline with $9,{ }^{20}$ was treated with 3 and in this case the formation of silylated ether $\mathbf{2 1}$ was observed. The transannular process has not been observed and even with an excess of $\mathbf{3}$ the $\mathrm{C}=\mathrm{N}$-group did not react. The X-ray analysis ${ }^{13}$ showed that the $\mathrm{CF}_{3}$-group is placed at exo-position (Fig.1).

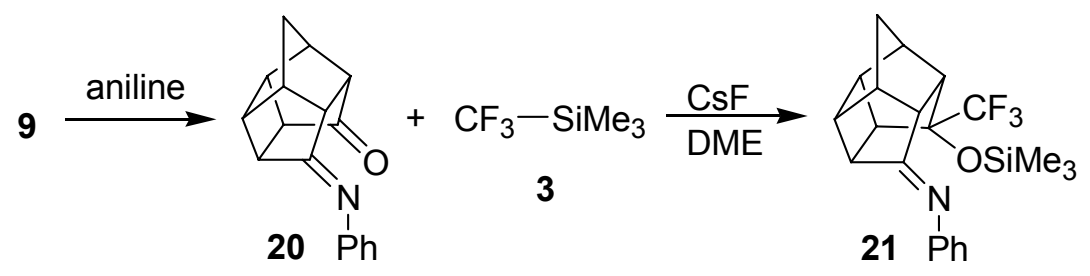

\section{Scheme 7}

In summary, the synthesis of new derivatives of trifluoromethylated polycyclic compounds $\mathbf{8}$, 13 and 19 using Ruppert's reagent was presented. Transannular cyclization led to hemiacetals 13 and 19, but it was not observed in the reaction with monoimine 20. In all cases the trifluoromethylation process proceeded stereoselectively and the trifluoromethyl group is placed at the exo position, exclusively.

\section{Experimental Section}

General Procedures. Melting points were determined in a capillary by using a MelTemp 2 apparatus and are uncorrected. IR spectra were obtained using a NEXUS FT-IR apparatus. MS spectra were obtained using a Varian MAT-112S spectrometer, which was operated in the CI mode. ${ }^{1} \mathrm{H}$-, ${ }^{13} \mathrm{C}$ - and ${ }^{19} \mathrm{~F}$-NMR spectra were recorded with a Bruker $300 \mathrm{MHz}$ in $\mathrm{CDCl}_{3}$ using 
TMS $(\delta=0 \mathrm{ppm})$ or $\mathrm{CFCl}_{3}$, respectively, as an internal standards. Elemental analysis and HRMS (Finnigan MAT95) data were obtained at Polish Academy of Sciences.

\section{Starting materials}

Trimethyl(trifluorometylhyl)silane (3), pentacyclo[5.4.0.0 $\left.0^{2,6} \cdot 0^{3,10} \cdot 0^{5,9}\right]$ undecane-8,11-dione (9), cesium fluoride and dry dimethoxyethane (DME) are commercialy avialable. Pentacyclo[5.4.0.0 $\left.0^{2,6} \cdot 0^{3,10} .0^{5,9}\right]$ undecane-8-one $^{21}(\mathbf{6})$ and tetracyclo $\left[6 \cdot 3 \cdot 0 \cdot 0^{4,11} .0^{5,9}\right]$ undecane-2,7dione $^{18}(\mathbf{1 8})$ were obtained according to described procedures.

\section{Reaction of Ketones 6, 9 and 18 with Ruppert's Reagent - General Procedure}

The corresponding ketone $\mathbf{6}, 9$ or 18 (1 mmol) was dissolved in dry DME $(3 \mathrm{ml})$ and to the solution catalytic amount of $\mathrm{CsF}$ (approx. $5 \mathrm{mg}$, dried at 200-300 ${ }^{\circ} \mathrm{C}$ ) was added under argon atmosphere. The mixture was protected against the moisture. Trimethyl(trifluorometylhyl)silane (3) $(1.1 \mathrm{mmol})$ was added in small portions through the septum and the mixture was stirred for $1.5 \mathrm{~h}$ at ambient temp. After this time $4 \mathrm{~N} \mathrm{HCl}(1 \mathrm{ml})$ was added and stirring was continued for an additional $1 \mathrm{~h}$. Then the reaction mixture was diluted with water $(5 \mathrm{ml})$ and extracted with dichloromethane $(3 \times 5 \mathrm{ml})$. Combined organic layers were dried over anhydrous magnesium sulfate. The solvent was removed in vacuo and crude products were purified by crystallization.

8-(Trifluoromethyl)pentacyclo $\left[5.4 .0 .0^{2,6} \cdot 0^{3,10} .0^{5,9}\right]$ undecane-8-ol (8). mp $126-127{ }^{\circ} \mathrm{C}$ (hexane), yield $60 \%(0.14 \mathrm{~g}, 0.6 \mathrm{mmol}) .{ }^{1} \mathrm{H} \mathrm{NMR}\left(\mathrm{CDCl}_{3}\right) \delta: 1.06-1.13(\mathrm{~m}, 1 \mathrm{H}), 1.24\left(\mathrm{AB}, \mathrm{J}_{\mathrm{AB}}=11 \mathrm{~Hz}\right.$, $1 \mathrm{H}), 1.70\left(\mathrm{AB}, \mathrm{J}_{\mathrm{AB}}=11 \mathrm{~Hz}, 1 \mathrm{H}\right), 1.97($ br. s, $1 \mathrm{H}, \mathrm{OH}), 2.30-2.39(\mathrm{~m}, 2 \mathrm{H}), 2.40-2.68(\mathrm{~m}, 6 \mathrm{H}), 2.83-$ 2.86(s, 1H). ${ }^{13} \mathrm{C}$ NMR $\left(\mathrm{CDCl}_{3}\right) \delta: 29.2(\mathrm{t}), 34.7(\mathrm{t}), 36.0(\mathrm{~d}), 38.3(\mathrm{~d}), 41.7(\mathrm{~d}), 42.1(\mathrm{~d}), 43.2(\mathrm{~d})$, 43.5(d), 45.7(d), 46.3(d), 82.3(q, $\left.{ }^{2} \mathrm{~J}_{\mathrm{C}-\mathrm{F}}=27 \mathrm{~Hz}\right), 126.4\left(\mathrm{q},{ }^{1} \mathrm{~J}_{\mathrm{C}-\mathrm{F}}=285 \mathrm{~Hz}\right) .{ }^{19} \mathrm{~F} \mathrm{NMR}\left(\mathrm{CDCl}_{3}\right) \delta$ : 76.4(s). IR (KBr) $\mathrm{cm}^{-1}: 3346 \mathrm{vs}, 2978 \mathrm{~s}, 2867 \mathrm{~s}, 1454 \mathrm{w}, 1393 \mathrm{~m}, 1308 \mathrm{~s}, 1288 \mathrm{~s}, 1264 \mathrm{~s}, 1158 \mathrm{vs}$, $1143 v s, 1127 \mathrm{~s}, 1080 \mathrm{~s}, 1026 \mathrm{~s}, 967 \mathrm{~m}, 700 \mathrm{~s}$. Anal. Calcd for $\mathrm{C}_{12} \mathrm{H}_{13} \mathrm{~F}_{3} \mathrm{O}: \mathrm{C} 62.60 ; \mathrm{H}$ 5.69. Found: C 62.61; H 5.57. MS (m/z): $248\left(\mathrm{M}+1+\mathrm{NH}_{3}\right)^{+}$

5-(Trifluoromethyl)-4-oxahexacyclo $\left[5.4 .1 .0^{2,6} \cdot 0^{3,10} \cdot 0^{5,9} \cdot 0^{8,11}\right]$ dodecane-3-ol (13). mp $116-117^{\circ}$ $\mathrm{C}$ (methanol), yield $65 \%(0.16 \mathrm{~g}, 0.65 \mathrm{mmol}) .{ }^{1} \mathrm{H} \mathrm{NMR}\left(\mathrm{CDCl}_{3}\right) \delta: 1.59\left(\mathrm{AB}, \mathrm{J}_{\mathrm{AB}}=11 \mathrm{~Hz}, 1 \mathrm{H}\right)$, $1.95\left(\mathrm{AB}, \mathrm{J}_{\mathrm{AB}}=11 \mathrm{~Hz}, 1 \mathrm{H}\right), 2.61-2.81(\mathrm{~m}, 6 \mathrm{H}), 2.83-3.11(\mathrm{~m}, 2 \mathrm{H}) .{ }^{13} \mathrm{C} \mathrm{NMR}\left(\mathrm{CDCl}_{3}\right) \delta: 41.9(\mathrm{~d})$, 42.0(d), 43.4(d), 43.5(t), 45.3(d), 45.5(d), 47.1(d), 55.3(d), 57.0(d), 89.3(q, $\left.{ }^{2} \mathrm{~J}_{\mathrm{C}-\mathrm{F}}=34 \mathrm{~Hz}\right)$, 120.0(s), 124.7(q, $\left.{ }^{1} \mathrm{~J}_{\mathrm{C}-\mathrm{F}}=275 \mathrm{~Hz}\right) .{ }^{19} \mathrm{~F}$ NMR $\left(\mathrm{CDCl}_{3}\right) \delta:-80.0(\mathrm{~s}) . \mathrm{IR}(\mathrm{KBr}) \mathrm{cm}^{-1}: 3348 \mathrm{vs}, 2993 \mathrm{vs}$, 2976vs, 2881m, 1722m, 1396s, 1351s, 1307m, 1191vs, 1176vs, 1138s, 1035s, 861m, $715 \mathrm{~m}$. Anal. Calcd for $\mathrm{C}_{12} \mathrm{H}_{11} \mathrm{~F}_{3} \mathrm{O}_{2}$ : C 59.02; H 4.54. Found: C 59.29; H 4.21. MS (m/z): 262 $\left(\mathrm{M}+1+\mathrm{NH}_{3}\right)^{+}$.

7-(Trifluoromethyl)-12-oxapentacyclo[6.3.1.0 $\left.{ }^{\mathbf{2 , 6}} \cdot \mathbf{0}^{\mathbf{3 , 1 0}} \cdot \mathbf{0}^{\mathbf{5 , 9}}\right]$ dodecane-1-ol (19). mp 90-92 ${ }^{\mathrm{o}} \mathrm{C}$ (hexane), yield $57 \%(0.14 \mathrm{~g}, 0.57 \mathrm{mmol}) .{ }^{1} \mathrm{H} \mathrm{NMR}\left(\mathrm{CDCl}_{3}\right) \delta: 1.65-1.79(\mathrm{~m}, 2 \mathrm{H}), 1.92-2.12(\mathrm{~m}$, $4 \mathrm{H}), 2.23-2.61(\mathrm{~m}, 5 \mathrm{H}), 2.78-3.15(\mathrm{~m}, 2 \mathrm{H}) .{ }^{13} \mathrm{C} \mathrm{NMR}\left(\mathrm{CDCl}_{3}\right) \delta: 35.5(\mathrm{t}), 37.7(\mathrm{t}), 41.7(\mathrm{~d}), 42.6(\mathrm{~d})$, 43.3(t), 47.8(d), 49.3(d), 55.2(d), 58.9(d), 89.5(q, $\left.{ }^{2} \mathrm{~J}_{\mathrm{C}-\mathrm{F}}=31 \mathrm{~Hz}\right), 117.3(\mathrm{~s}), 125.8\left(\mathrm{q},{ }^{1} \mathrm{~J}_{\mathrm{C}-\mathrm{F}}=278 \mathrm{~Hz}\right)$. IR $(\mathrm{KBr}) \mathrm{cm}^{-1}: 3399 \mathrm{brs}, 2971 \mathrm{~s}, 2947 \mathrm{~m}, 1377 \mathrm{~m}, 1388 \mathrm{~s}, 1299 \mathrm{~s}, 1219 \mathrm{~s}, 1170 \mathrm{vs}, 1145 \mathrm{vs}, 1119 \mathrm{~s}$, 
1102s, 1062s, 1042s, 1012m, 947m. HRMS: Calcd. for $\mathrm{C}_{12} \mathrm{H}_{13} \mathrm{~F}_{3} \mathrm{O}_{2}$ : 246.0868; Found: 246.0863. MS-EI (m/z): $246\left(\mathrm{M}^{+}, 32\right), 224(100)$, 186(72), 91(50).

Phenyl(11-trifluoromethyl-11-trimethylsilanyloxypentacyclo $\left[5.4 .0 .0^{2,6} \cdot 0^{3,10} .0^{5,9}\right]$ undec-8ylidene)amine (21). Dione $9(250 \mathrm{mg}, 1.15 \mathrm{mmol})$ was dissolved in THF (10 ml) and cooled down in ice-bath. To this solution aniline $(0.5 \mathrm{ml}$, excess $)$ was added dropwise and after approx. $30 \mathrm{~min}$. white precipitate was filtered off. This half-product was suspended in benzene and dehydrated in boiling toluene using Dean-Stark aparatus. After $1 \mathrm{~h}$ toluene was removed in vacuo and obtained imine 20 (200 mg, $0.80 \mathrm{mmol}, 70 \%)$ was dissolved in dry DME (3 ml). To this solution catalytic amount of CsF (approx. $5 \mathrm{mg}$ ) was added under argon atmosphere and the mixture was protected against the moisture. The Ruppert's reagent $\mathbf{3}(1.0 \mathrm{mmol})$ was added in small portions through the septum and the mixture was stirred for $1.5 \mathrm{~h}$ at ambient temp. After this time water $(1 \mathrm{ml})$ was added and stirring was continued for additional $1 \mathrm{~h}$. Than the reaction mixture was diluted with water $(5 \mathrm{ml})$ and extracted with dichloromethane $(3 \times 5 \mathrm{ml})$. Combined organic layers were dried over anhydrous magnesium sulfate. The solvent was removed in vacuo and crude product was purified by chromatography on preparative plates $\left(\mathrm{SiO}_{2}, \mathrm{CH}_{2} \mathrm{Cl}_{2} /\right.$ hexane, 1:4). Obtained product 21 was recrystalized from $\mathrm{MeOH}$ to give colorless crystalls (150 mg, 0.38 mmol, 48\%), mp 140-142 ${ }^{\circ} \mathrm{C}$.

${ }^{1} \mathrm{H}$ NMR $\left(\mathrm{CDCl}_{3}\right) \delta: 0.14(\mathrm{~s}, 9 \mathrm{H}), 1.50\left(\mathrm{AB}, \mathrm{J}_{\mathrm{AB}}=11 \mathrm{~Hz}, 1 \mathrm{H}\right), 1.89\left(\mathrm{AB}, \mathrm{J}_{\mathrm{AB}}=11 \mathrm{~Hz}, 1 \mathrm{H}\right), 2.46-$ 2.96(m, 8H), 6.92-7.11(m, 3H), 7.26-7.34(m, 2H). ${ }^{13} \mathrm{C} \mathrm{NMR}\left(\mathrm{CDCl}_{3}\right) \delta: 33.3(\mathrm{~d}), 37.4(\mathrm{t}), 38.9(\mathrm{~d})$, 41.4(d), 42.2(t), 50.7(d), 51.1(d), 82.7(q, $\left.{ }^{2} \mathrm{~J}_{\mathrm{C}-\mathrm{F}}=27 \mathrm{~Hz}\right), 122.4(\mathrm{~d}), 124.0(\mathrm{~d}), 126.9\left(\mathrm{q},{ }^{1} \mathrm{~J}_{\mathrm{C}-\mathrm{F}}=286\right.$ $\mathrm{Hz}), 128,3(\mathrm{~d}), 149.7(\mathrm{~s}), 178.8(\mathrm{~s}) .{ }^{19} \mathrm{~F} \mathrm{NMR}\left(\mathrm{CDCl}_{3}\right) \delta:-75.2(\mathrm{~s}) . \mathrm{IR}(\mathrm{KBr}) \mathrm{cm}^{-1}: 2997 \mathrm{~s}, 2898 \mathrm{~m}$, $2870 \mathrm{~m}, 1672 \mathrm{~m} \mathrm{1604m}, 1596 \mathrm{~m}, 1488 \mathrm{~m}, 1406 \mathrm{~m}, 1339 \mathrm{~s}, 1307 \mathrm{~m}, 1254 \mathrm{vs}, 1159 \mathrm{vs}, 1140 \mathrm{vs}, 1042 \mathrm{~s}$, 886s, 864s, 846s, 756m 701m. Anal. Calcd for $\mathrm{C}_{21} \mathrm{H}_{24} \mathrm{~F}_{3} \mathrm{NOSi}$ : C 64.43; H 6.18. Found: C 64.18; H 6.07. MS (m/z): $392(\mathrm{M}+1)^{+}$.

\section{Acknowledgements}

Authors thank the Rector of University of Lodz for financial support (Grant nr 505/712).

\section{References}

1. (a) Olah, G. A.; Chambers, R. P.; Prakash, G. K. S. Synthetic Fluorine Chemistry; J. Wiley \& Sons: New York, 1992. (b) Smart, B. E. Organofluorine Chemistry, Principles and Commercial Applications; Plenum Press: New York, 1994, pp 57-88. (c) Methoden der organischen Chemie (Houben-Weyl); Vol. E10a-b; Baasner, B.; Hagemann, H,; Tatlow, J. C.; Eds.; Thieme-Stuttgart: 1999/2000, Vol. E10a-b.

2. McClinton, M. A.; McClinton, D. A. Tetrahedron 1992, 48, 6555. 
3. Dmowski, W. In Methoden der organischen Chemie (Houben-Weyl); Baasner, B.; Hagemann, H, Eds.; Thieme-Stuttgart: 1999, Vol. E10a, pp 321-395.

4. Umemoto, T.; Ishihara, S. Tetrahedron Lett. 1990, 31, 3579.

5. (a) Singh, R. P.; Shreeve, J. M. Tetrahedron, 2000, 56, 7613. (b) Prakash, G. K. S.; Mandal M. J. Fluorine Chem. 2001, 112, 123. (c) Kim, J.; Shreeve, J. M. Org. Biomol. Chem. 2004, 2, 2728. (d) Song, J. J.; Tan, Z.; Reeves, J. T.; Gallou, F.; Nathan, K.; Yee, N. K.; Senanayake, C. H. Org. Lett., 2005, 7, 2193.

6. (a) Ruppert, I.; Schlich, K.; Volbach, W. Tetrahedron Lett. 1984, 24, 2195. (b) Thayer, A. M. Chem. Eng. News, 2006, 84, 15.

7. Prakash, G. K. S.; Krishnamurti, R.; Olah, G. A. J. Am. Chem. Soc. 1989, 111, 393.

8. Prakash, G. K. S.; Panja, C.; Vaghoo, H.; Surampudi, V.; Kultyshev, R.; Mandal, M.; Rasul, G.; Mathew, T.; Olah, G. A. J. Org. Chem. 2006, 71, 6806 and references cited therein.

9. Marchand, A. P. Aldrichimica Acta, 1995, 28, 95.

10. Krishnamurti, R.; Bellow, D. R.; Prakash, G. K. S. J. Org. Chem. 1991, 56, 984.

11. (a) Sasaki, T.; Eguchi, S.; Kiriyama, T.; Hiroaki, O. Tetrahedron 1974, 30, 2707. (b) Marchand, A. P.; Arney, B. E. Jr.; Dave, P. R.; Satyanarayana, N. J. Org. Chem., 1988, 53, 1088. (c) Liebenberg, W.; Van der Walt, J. J.; Van der Schyf, C. J. Pharmazie 2000, 55, 833. (d) Marchand, A. P.; Keith, J. M.; Alihodzic, S.; Ganguly, B.; Somers, A.; W. Hariprakasha, H. K.; Power, T. D.; Watson W. H.; Bodige, S. G. Struct. Chem. 2001, 12, 313.

12. (a) Romański, J.; Mlostoń, G. Synthesis, 2002, 1355. (b) Romański, J.; Marchand, A. P. Pol. J. Chem., 2004, 78, 223.

13. Linden, A.; Romański, J.; Mlostoń, G.; Heimgartner, H. Acta Crystallogr. Sect. C, 2005, C61, 221.

14. Quast, H.; Becker, Ch.; Witzel, M.; Peters, E.-M.; Peters K.; Schnering, H. G. von, Liebigs Ann. Org. Bioorg. Chem 1996, 6, 985.

15. Singh, R. P.; Twamley, B.; Shreeve, J. M. J. Fluorine Chem. 2001, 112, 329.

16. (a) Romański, J.; Mlostoń, G.; Żmudzka, K. $47^{\text {th }}$ Annual Meeting of Polish Chemical Society, Wroclaw, Poland, September 12-17, 2004, Materials, K012, 58; (b) Romański, J. Polish J. Chem. 2007, 81, 187-191.

17. Prakash, G. K. S.; Yudin, A. K. Chem. Rev., 1997, 97, 757.

18. Wenkert E.; Yoder, J. E. J. Org. Chem., 1970, 35, 2986.

19. Bott, S. G.; Rajagopal, D.; Marchand, A. P.; Kumar, K .A. J. Chem. Cryst., 1996, $26,425$.

20. Sasaki, T.; Eguchi, S.; Kiriyama, T.; Hiroaki, O. Tetrahedron, 1974, 30, 2707.

21. (a) Martins, F. J. C.; Viljoen, A. M.; Kruger, H. G.; Fourie, L.; Roscher, J.; Joubert, A. J.; Wessels, P. L. Tetrahedron, 2001, 57, 1601. (b) Romański, J.; Mlostoń, G.; Linden, A.; Heimgartner, H. Pol. J. Chem., 2005, 79, 973. 